\title{
A new species, Gypsophila malyerii (Caryophyllaceae) from Turkey
}

\section{Ergin Hamzaoğlu ${ }^{1}$ (D), Murat Koç ${ }^{2}$ (D) \& Mevlüde Nur Topal ${ }^{3}$ (D)}

Summary. Gypsophila malyerii Hamzaoğlu \& Koç, a new species of sect. Capituliformes, is described and illustrated from Turkey. Information on distribution, habitat and conservation status are given. The most similar species is G. osmangaziensis. The morphology and micromorphology of seed and pollen characters of the two closely related species are compared.

Key Words. micromorphology, pollen, seed, taxonomy.

\section{Introduction}

One of the largest families in the world, Caryophyllaceae contains about 100 genera and 3000 species (Hernández-Ledesma et al. 2015). It mostly occurs in the northern hemisphere and is less common in the southern hemisphere (Özhatay \& Kültür 2006; Hernández-Ledesma et al. 2015; Koç et al. 2019). In recent years, molecular studies have been carried out on many genera of the Caryophyllaceae family (Fior \& Karis 2007; Fu et al. 2008; Frajman et al. 2009; Rautenberg et al. 2010).

Increased molecular phylogenetic investigations of the family have resulted in new information about the family classification, including the creation of a new tribe, Eremogoneae Rabeler \& W.L.Wagner (Bittrich 1993; Harbaugh et al. 2010). Molecular studies on Petrorhagia, Velezia and Gypsophila revealed the relationship among related taxa (Korkmaz \& Doğan 2015; Poyraz et al. 2012; Hilooğlu et al. 2016). Molecular phylogenetic studies based on ITS and plastid trnQrps16 DNA in the largest genera (Gypsophila L., Dianthus L., Arenaria L., Minuartia L. and Silene L.) have resulted in revised treatments including new genera and synonymy (Dillenberger \& Kadereit 2014; Madhani et al. 2018; Sadeghian et al. 2015).

The genus Gypsophila L. described by Linnaeus, comprises about 140 species, representing the fourth largest genus of the Caryophyllaceae Juss. (Mabberley 2018) and slightly more than $50 \%$ of these species occur in Turkey (Barkoudah et al. 1964). The main centre of diversity for Gypsophila is the temperate regions of Eurasia, Africa, Pacific Islands, with one species extending to Australia; introduced in North and South America (Madhani et al. 2018).
In Turkey, Gypsophila has 4 groups and 10 sections (Huber-Morath 1967; Davis et al. 1988; Ataşlar 2000). As a result of recent studies, new species have been added to the genus: G. osmangaziensis Ataşlar \& Ocak, G. munzurensis Armağan, G. turcica Hamzaoğlu, G. yusufeliensis Budak, G. torulensis Koç and G. guvengorkii Armağan, Özgökçe \& A.Çelik. The total number of taxa has therefore increased to 63 in Turkey (Ataşlar \& Ocak 2005; Hamzaoğlu 2012; Budak 2012; Koç 2013; Armağan 2016; Armağan et al. 2017; Barkoudah 1962; Huber-Morath 1967; Davis et al. 1988; Ataşlar 2000; Özçelik \& Özgökçe 2021).

The genus Gypsophila includes annuals, biennials and perennial herbs or semishrubs. It is related to Bolanthus (Ser.) Rchb., Ankyropetalum Fenzl and Acanthophyllum C.A.Mey. (Davis 1967; Davis et al. 1988). Previous studies have found that pollen and seed features provide taxonomically important micromorphological characters (Cronquist 1968; Amini et al. 2011). Atasslar et al. (2009) reported that variation in pollen morphology of 12 Gypsophila species could be an indication of their genetic differences and therefore could be useful in differentiating taxa.

\section{Materials and Methods}

The first author collected some interesting Gypsophila specimens from the Beypazarı district (Ankara province, Inner Anatolia) in Turkey. A large number of specimens from different populations were later collected from the Beypazarı district. These specimens were compared with the relevant literature (Barkoudah 1962; Barkoudah et al. 1964; Davis et al. 1988; Huber-Morath 1967; Bojňanský \& Fargašová

\footnotetext{
Accepted for publication 6 April 2021. Published online 21 August 2021

1 Department of Mathematics and Science Education, Gazi Faculty of Education, Gazi University, 06500, Ankara, Turkey.

2 Department of Traditional, Complementary and Integrative Medicine, Institute of Public Health, Ankara Yıldırım Beyazıt University, Keçiören, Ankara, Turkey. e-mail: aybumuratkoc@hotmail.com

3 Department of biotherapeutic products research and development, Institute of Public Health, Ankara Yıldırım Beyazıt University, Keçiören, Ankara, Turkey.
} 


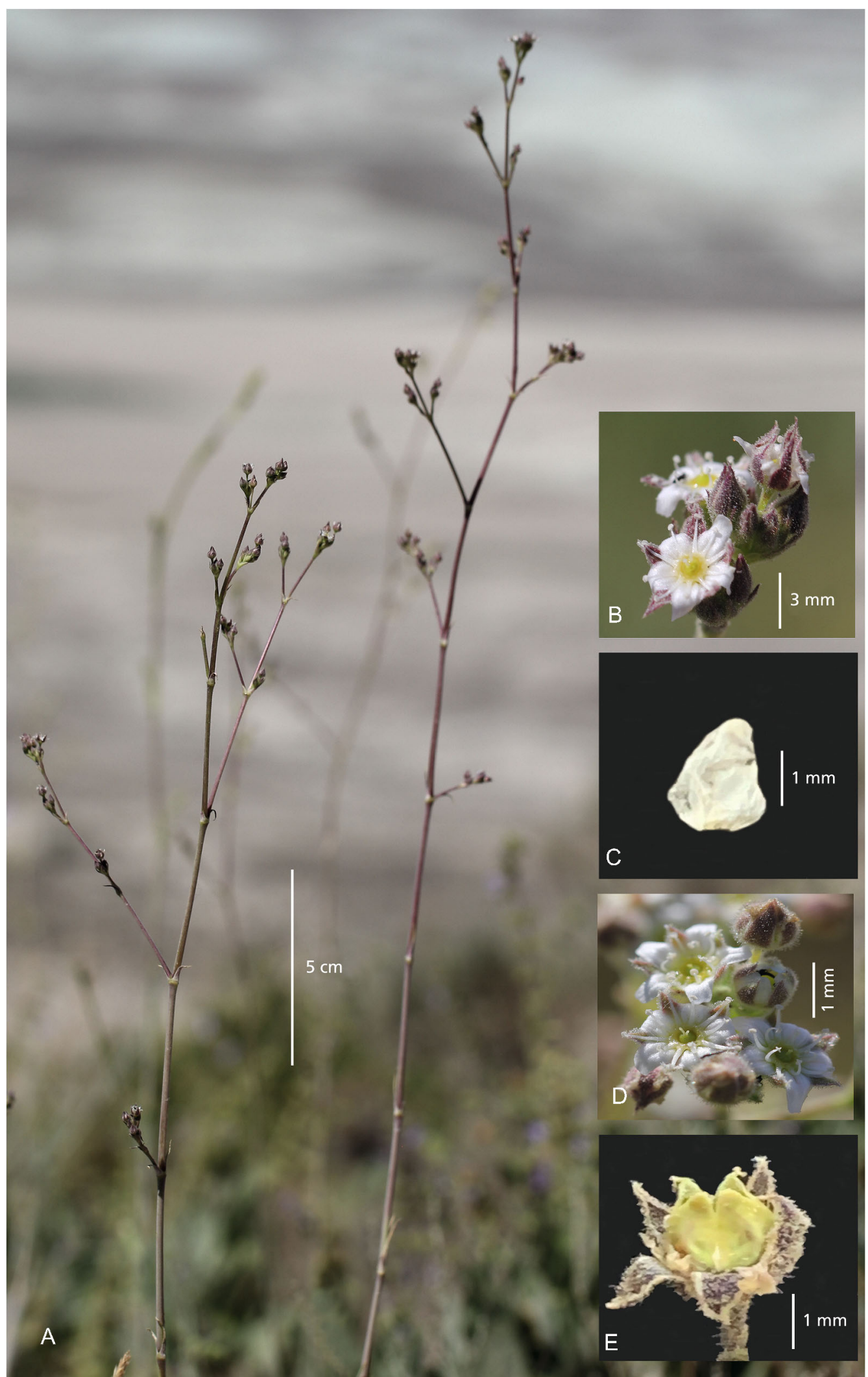

Fig. 1. Gypsophila malyerii. A habit; B flower; C petal; D inflorescence; E capsule. PHOTOS: ERGIN HAMZAOĞLU. 


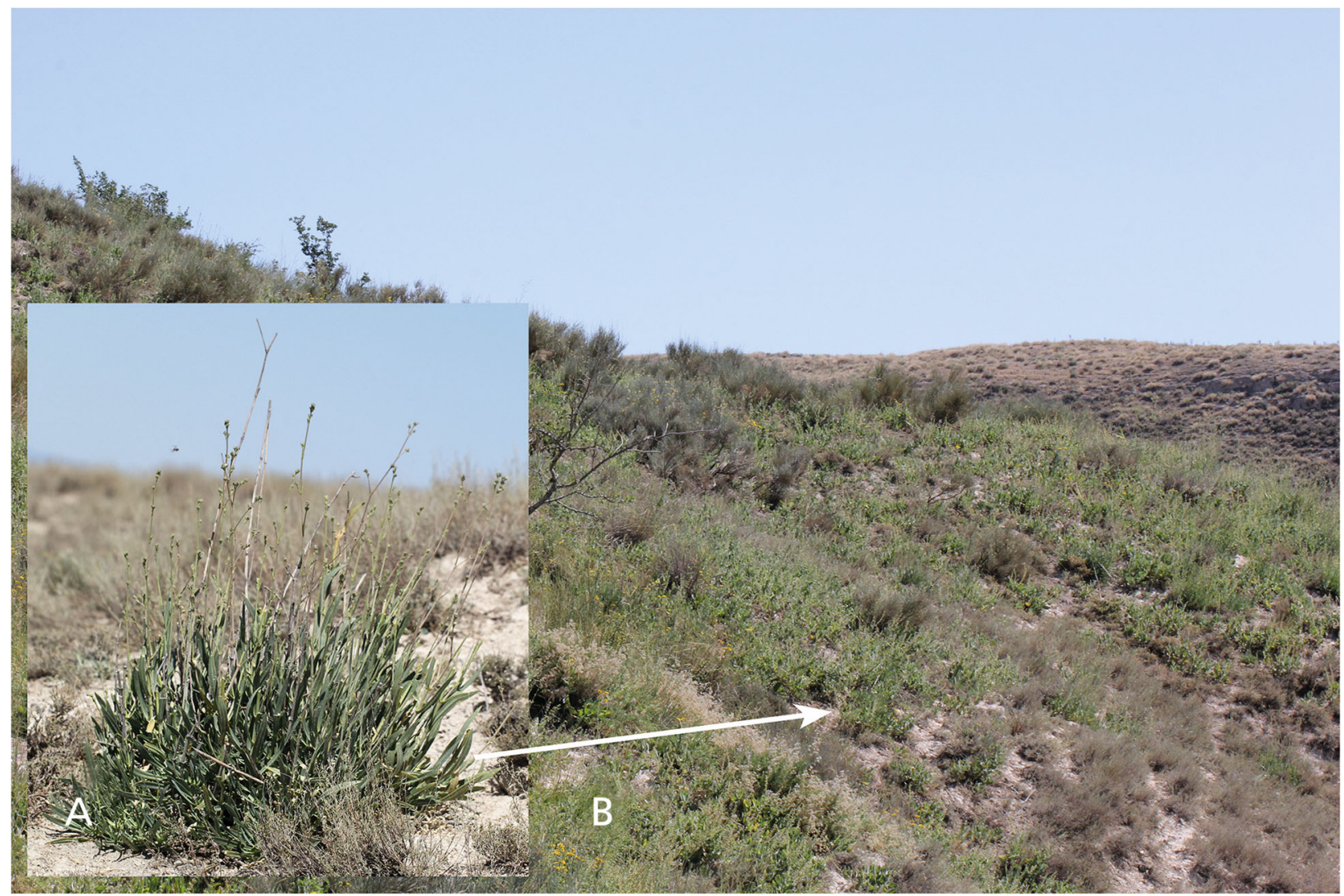

Fig. 2. Gypsophila malyerii. A habit; B habitat general view. PHOTOS: ERGIN HAMZAOĞLU.

2007; Rechinger 1964, 1988; Shishkin 1970; Zohary 1966) and with the specimens kept in ANK, EGE, GAZI, ISTE, ISTO and KNYA (abbreviations follow Thiers 2021) and specimens from virtual herbaria at $\mathrm{E}$ and $\mathrm{G}$ were also examined. From each population, a minimum of five mature seeds of $G$. malyerii and G. osmangaziensis were placed onto stubs using doublesided adhesive tape and samples were coated with layer of gold in a Polaron SC7620 rotating and tilting vacuum coating apparatus for $60 \mathrm{~s}$ and scanned using a JEOL 5600 LV SEM (Scanning Electron Microscopy) by $20-\mathrm{kV}$ accelerating voltage (Walker 1974a, 1974b). Minimum, maximum and mean values of the following pollen morphological characters were calculated: pollen ornamentation, pollen diameter, pore diameter, pollen shape, distance between two pores, operculum diameter, pore numbers, spinule numbers, punctum numbers. Measurements were made on 20 - 30 pollen grains and based on the ratio of polar axis to equatorial axis $(\mathrm{P} / \mathrm{E})$, the pollen shape class was identified by using Erdtman's system (Erdtman 1969). Pollen morphologies were determined by using the glossary of pollen and spore terminology of Punt et al. (2007).

Minimum, maximum and mean values of seed morphological characters were calculated as follows: length, width, colour, seed shape and surface type.
Morphological measurements were made using a ruler with $0.5 \mathrm{~mm}$ accuracy and an ocular micrometer. Seed morphology follows the terminology of Yildiz (2002) and Amini et al. (2011). Measurements of pollen and seed were made with the AlaMet 0.06 program. The average of the measured samples was calculated with Microsoft Office Excel. Gypsophila malyerii habit photographs were taken with an OLYMPUS C-5060 digital camera.

\section{Taxonomic Treatment}

Gypsophila malyerii Hamzaoğlu $\mathcal{E}$ Koç sp. nov. Type: Turkey. B4 Ankara: Beypazarı, between HarmanakUşakbükü, 36T0392454-4430814, 510 m, 22 Aug. 2020, marn areas, Hamzaoğlu E Koç 7825 (holotype GAZI; isotypes ANK, GAZI).

http://www.ipni.org/urn:lsid:ipni.org:names:77218375-1

Perennial, with a woody rhizome, \pm glaucous. Stems single, with a thick stock and ascending-erect, $45-80$ $\mathrm{cm}, 6-8 \mathrm{~mm}$ diam., glabrous below, branches of inflorescence glandular-hairy above. Basal leaves oblanceolate, fleshy, lamina 50 - $80 \mathrm{~mm}$ long, 5 - $8 \mathrm{~mm}$ wide; stem leaves oblanceolate, 30 - $70 \mathrm{~mm}$ long, 3 $6 \mathrm{~mm}$ wide. Inflorescence lax dichasial, 3-10 mm diam., 

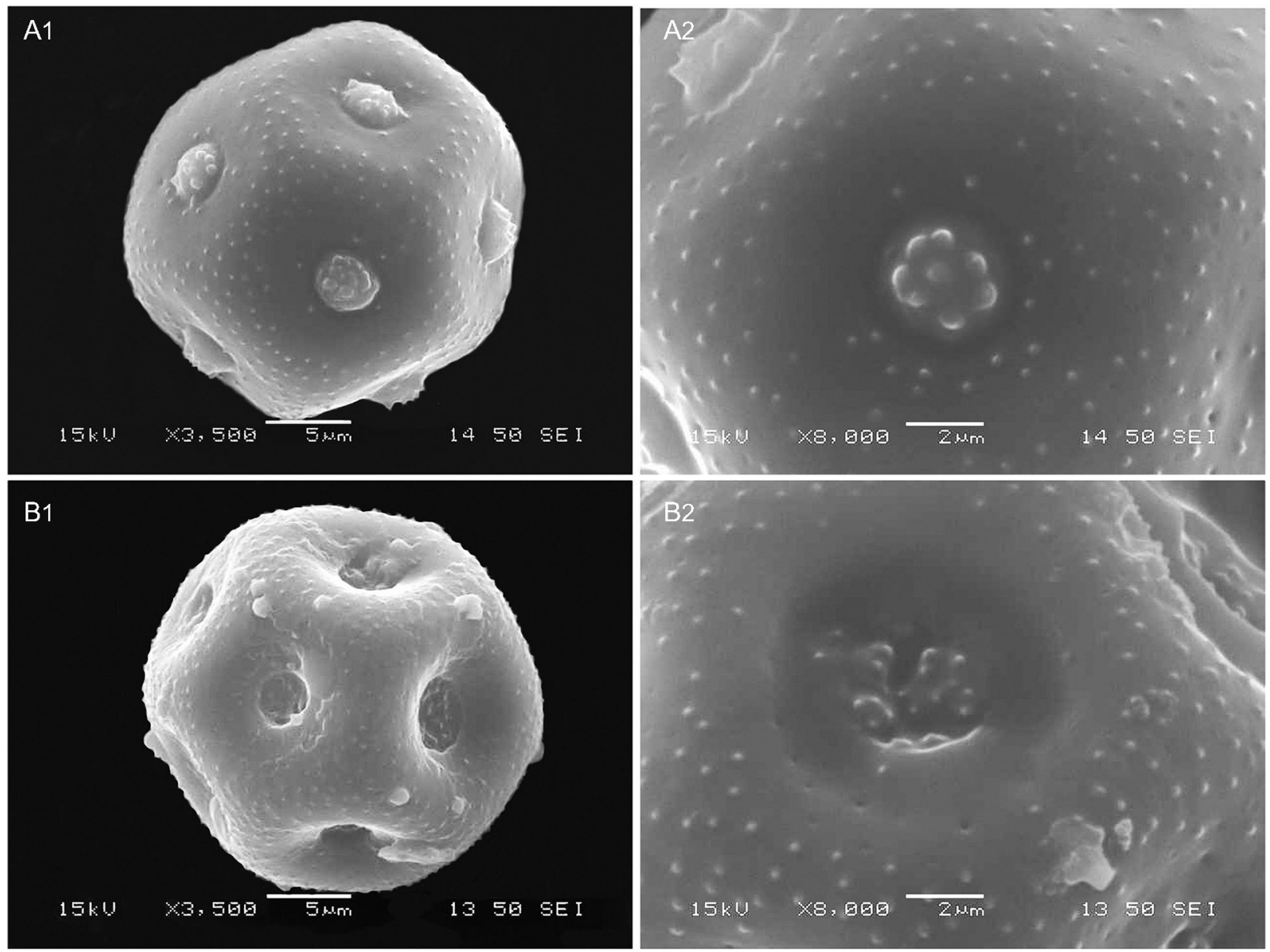

Fig. 3. SEM micrographs of pollen grains. A1, A2 Gypsophila malyerii; B1, B2 G. osmangaziensis.

$(8-) 4-16$ (- 20)-flowered; peduncles $4-42 \mathrm{~mm}$. Bracts deltate, acuminate, scarious with a brownish midrib, entire to minutely undulate, glandular, $2-3$ mm. Inner bracts deltoid to oblong acuminate. Alar pedicels $3-5 \mathrm{~mm}$. Calyx campanulate-turbinate, cleft to $1 / 2$ into acuminate teeth with scarious margins, scabrid, 2.5 - $4 \mathrm{~mm}$. Petals white, ovate, obtuse, 2.5 $4 \mathrm{~mm}$. Capsule globose, $2.5-4 \mathrm{~mm}$ long, as long as calyx. Seeds 2 in each capsule, tubercles obtuse, c. $2.5 \times$ $4 \mathrm{~mm}$. Figs 1, 2.
RECOGNITION. Gypsophila malyerii is related to G. osmangaziensis Ataşlar \& Ocak. However, it differs from $G$. osmangaziensis in the bracts glandular hairy (not scabrid); alar pedicels $3-5 \mathrm{~mm}$ long (not $1-1.5$ $\mathrm{mm}$ ); calyx $2.5-4 \mathrm{~mm}$ long (not $2-2.5 \mathrm{~mm}$ ); petals ovate, as long as calyx (not oblong-spathulate, 1.5 times as long as calyx). The seed and pollen morphology of the two species are also different.

DISTRIBUTION. This new species is known only from the type locality in Turkey (Map 1).

Table 1. Comparison of the diagnostic characters of Gypsophila malyerii and G. osmangaziensis.

\begin{tabular}{lll}
\hline \hline & & Species \\
\cline { 2 - 3 } Character & \multicolumn{1}{c}{ Gypsophila malyerii } & Gypsophila osmangaziensis \\
\hline Stem length $(\mathrm{cm})$ & $45-80$ & $100-180$ \\
Inflorescence & lax cluster & globose cluster \\
Bracts & glandular hairy & scabrid \\
Alar pedicel length $(\mathrm{mm})$ & $4-6$ & 1.5 \\
Calyx length (mm) & $2.5-4$ & $2-2.5$ \\
Petals & 1.5 times as long as calyx, oblong-spatulate & as long as calyx, ovate \\
\hline
\end{tabular}


Table 2. Pollen morphological features of Gypsophila malyerii and the closely related species G. osmangaziensis.

\begin{tabular}{|c|c|c|c|}
\hline \multirow[b]{2}{*}{ Character } & & \multicolumn{2}{|c|}{ Species } \\
\hline & & Gypsophila malyerii & Gypsophila osmangaziensis \\
\hline \multirow[t]{3}{*}{ Polar axes $(\mu \mathrm{m})$} & Max. & 20.54 & 21.90 \\
\hline & Min. & 23.59 & 25.63 \\
\hline & Mean \pm SD & $22.05 \pm 1.02$ & $23.21 \pm 1.34$ \\
\hline \multirow{3}{*}{ Equatorial axes $(\mu \mathrm{m})$} & Max. & 24.13 & 22.90 \\
\hline & Min. & 25.50 & 27.22 \\
\hline & Mean \pm SD & $24.70 \pm 0.48$ & $25.06 \pm 1.66$ \\
\hline \multirow[t]{3}{*}{ Pollen diam. $(\mu \mathrm{m})$} & Max. & 22.54 & 21.63 \\
\hline & Min. & 24.59 & 25.73 \\
\hline & Mean \pm SD & $23.78 \pm 0.89$ & $23.32 \pm 1.36$ \\
\hline \multirow{3}{*}{ Distance between two pores $(\mu \mathrm{m})$} & Max. & 4.50 & 3.89 \\
\hline & Min. & 5.90 & 6.13 \\
\hline & Mean \pm SD & $5.41 \pm 0.37$ & $5.00 \pm 0.75$ \\
\hline \multirow[t]{3}{*}{ Pore diameter $(\mu \mathrm{m})$} & Max. & 2.54 & 2.31 \\
\hline & Min. & 4.50 & 4.03 \\
\hline & Mean \pm SD & $3.88 \pm 0.63$ & $3.28 \pm 0.65$ \\
\hline \multirow[t]{3}{*}{ Operculum diam. $(\mu \mathrm{m})$} & Max. & 1.36 & 1.18 \\
\hline & Min. & 2.54 & 3.84 \\
\hline & Mean \pm SD & $1.97 \pm 0.33$ & $2.89 \pm 0.66$ \\
\hline Pollen ornamentation & & microechinate- punctate-perforate & microechinate-punctate-perforate \\
\hline Pollen shape & & oblate-spheroidal & oblate-spheroidal \\
\hline Number of pores & & $10-12$ & $11-13$ \\
\hline Number of spinules & & $8-6$ & $10-12$ \\
\hline Number of punctae & & $5-7$ & $6-8$ \\
\hline
\end{tabular}

Min. minimum; Max. maximum; SD standard deviation.

SPECIMENS EXAMINED. TURKEY. Gypsophila malyerii: Turkey, B4 Ankara: Beypazarı, between HarmanakUşakbükü, 36T0392454-4430814, 510 m, 22 Aug. 2020, marn areas, Hamzaoğlu $\mathcal{E}$ Koç 7825 (holotype GAZI; isotypes ANK, GAZI). Gypsophila osmangaziensis: B3 Eskişehir: Tepebası, around Takmak village, 36S0273515-4399472, 925 m, 5 Sept. 2020, marn and gypsum areas, Hamzaoğlu $\mathcal{E}^{\circ}$ Koç 7836 (GAZI).

HABITAT. Gypsophila malyerii grows in marn areas. Species growing alongside it include: Artemisia santonicum L., Genista sessilifolia DC., Inula aucheriana DC., Reaumuria alternifolia (Labill.) Britten, Salvia halophila Hedge, Hypericum turcicum Özbek \& Hamzaoğlu, Salvia halophila Hedge, Taraxacum farinosum Hausskn. \& Bornm. ex Hand.-Mazz., Gypsophila parva Barkoudah, Thymelaea passerina (L.) Coss. \& Germ., Plantago maritima L., Euphorbia macroclada Boiss., Thymus leucostomus Hausskn. \& Velen.

CONSERVATION STATUS. Gypsophila malyerii is known only from one population in the locality of Beypazarı district (Ankara province). It grows in an area covering about $50 \mathrm{~km}^{2}$. No threat has been observed for the species in the area; the number of individuals is quite high. Based on available data, it is proposed that the species should be evaluated as Least Concern (LC) (IUCN 2012).

PHENOLOGY. Gypsophila malyerii was observed flowering from July to August and fruiting in August.

Table 3. Seed morphological features of Gypsophila malyerii and the closely related species G. osmangaziensis.

\begin{tabular}{|c|c|c|c|}
\hline & & \multicolumn{2}{|c|}{ Species } \\
\hline \multicolumn{2}{|l|}{ Characters } & Gypsophila malyerii & Gypsophila osmangaziensis \\
\hline \multirow[t]{3}{*}{ Length (mm) } & Min. & 1.1 & 1.4 \\
\hline & Max. & 1.3 & 1.5 \\
\hline & Mean \pm SD & $1.2 \pm 0.07$ & $1.4 \pm 0.03$ \\
\hline \multirow[t]{2}{*}{ Width (mm) } & Min. & 0.8 & 1.1 \\
\hline & Mean \pm SD & $0.9 \pm 0.08$ & $1.2 \pm 0.05$ \\
\hline Seed shape & & orbicular-reniform & orbicular-reniform \\
\hline Colour & & dull black & dull black \\
\hline Surface type & & aculeate & verrucose \\
\hline Margine & & dentate & crenulate \\
\hline
\end{tabular}

Min. minimum; Max. maximum; SD standard deviation. 

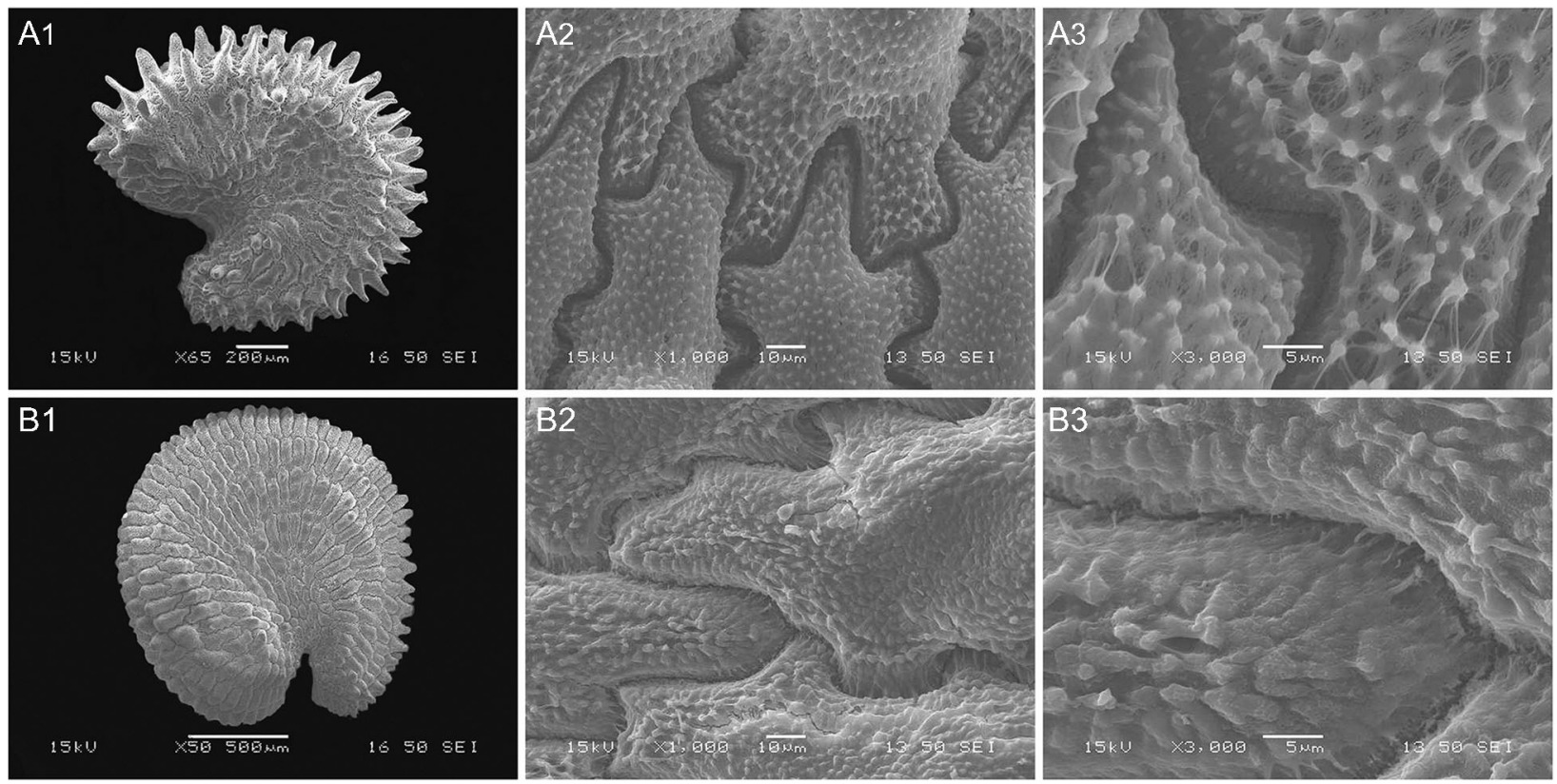

Fig. 4. SEM micrographs of seeds. A1, A2, A3 Gypsophila malyerii; B1, B2, B3 G. ozmangaziensis.

ETYMOLOGY. The species epithet is in honour of the eminent botanist Prof. Dr Hulusi Malyer (Uludağ University, Bursa/Turkey), who sadly died of Covid-19. NOTES. The pedicellate flowers, not in dense globose clusters, and the glandular hairy inflorescence, would place Gypsophila malyerii in group D in the Flora of Turkey and Aegean Islands (Huber-Morath 1967). However, no sectional separation was made in this study for a campanulate-turbinate calyx.

The genus Gypsophila grows mostly in steppes on calcareous hills, dry or rocky slopes, and sandy soils, sometimes weeds on farms, some species ruderals growing along roadsides (Madhani et al. 2018). Taxa of the genus Gypsophila have a wide distribution in Turkey, with about 63 taxa consisting of annual and perennial species (HuberMorath 1967). The specimens collected from Beypazarı district (Ankara province) show similarity to $G$. osmangaziensis in having stems glabrous below and glandular hairy above, long leaves, long peduncles, bract shape, calyx shape, petal colour and capsule shape.

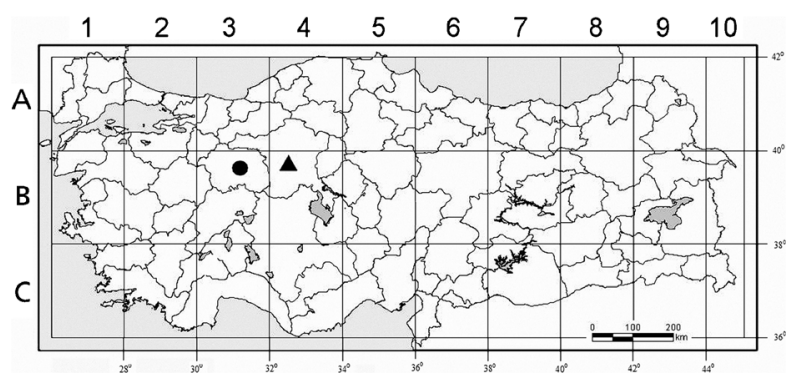

Map 1. Distribution map of Gypsophila osmangaziensis (•) and Gypsophila malyerii ( $\mathbf{\Delta})$ in Turkey.
However, they differ from this taxon in their lax dichasial inflorescence, glandular hairy bracts, $3-5 \mathrm{~mm}$ long pedicels, $2.5-4 \mathrm{~mm}$ long calyx and ovate petals as long as the calyx (Table 1).

\section{Pollen and seed morphology}

The pollen and seed morphology of Gypsophila malyerii and the closely related $G$. osmangaziensis were compared and some differences were determined with regard to these characteristics (Tables 2 \& 3, Figs 3 \& 4). Pollen size ranges from $20.54-25.63 \mu \mathrm{m}$ in polar axes and $22.90-27.22 \mu \mathrm{m}$ in equatorial axes. Cui et al. (2019) investigated the variation in pollen shape of 17 Chinese species of Gypsophila. They classified the Gypsophila species investigated into three groups, based on pollen ornamentation: microechinate, microechinate-punctate, and microechinate-punctateperforate. Atasslar et al. (2009) observed the pollen grains of 12 Gypsophila taxa studied from Turkey to be polyporate and spheroidal. In our study, the pollen shape for both $G$. malyerii and $G$. osmangaziensis was found to be similar: oblate-spheroidal, with microechinate-punctate-perforate ornamentation. The results of our pollen morphology studies are summarised in Table 2.

Ataşlar \& Ocak (2005) reported that the seeds of Gypsophila osmangaziensis were dark-brown or dull black in colour and reniform in shape. Armağan et al. (2017) described the seeds of G. guvengorkii as brownish-black, reniform $(1-1.2 \times 1.2-1.4 \mathrm{~mm})$ with obtuse tubercles. In our study, the seed shape was 
found to be orbicular-reniform in both $G$. malyerii and G. osmangaziensis and the colour dull black (Table 3).

\section{References}

Amini, E., Zarre, S. \& Assadi, M. (2011). Seed micromorphology and its systematic significance in Gypsophila (Caryophyllaceae) and allied genera. Nordic J. Bot. 29 (6): 660 - 669.

Armağan, M. (2016). Gypsophila munzurensis (Caryophyllaceae), a new species from Tunceli (Turkey). Phytotaxa. 275 (2): 175 - 180.

Özgökçe, F. \& Çelik, A. (2017). Notes on the genus Gypsophila (Caryophyllaceae) in Turkey, with a description of G. guvengorkii sp. nov. Phytotaxa 295 (3): $271-275$.

Ataşlar, E. (2000). Gypsophila L. In: A. Güner, N. Özhatay, T. Ekim \& K. H. C. Başer (eds), Flora of Turkey and the East Aegean Islands. Vol. 11: 49 - 50. Edinburgh University Press, Edinburgh. \& Ocak, A. (2005). Gypsophila osmangaziensis (Caryophyllaceae), a new species from Central Anatolia, Turkey. Ann. Bot. Fenn. 42: 57 - 60. İsmühan, P. E. \& Süleyman, T. (2009). Pollen morphology of some Gypsophila L. (Caryophyllaceae) species and its taxonomic value. Turk. J. Bot. 33: 335 - 351.

Barkoudah, Y. I. (1962). A Revision of Gypsophila, Bolanthus, Ankyropetalum and Phryna. Wentia 9: 1 - 3. , Chater, A. O. \& Akeroyd, J. R. (1964). Gypsophila L. In: T. G. Tutin, V. H. Heywood, N. A. Burges, D. H. Valentine, S. M. Walters \& D. A. Webb (eds), Flora Europaea, Vol. 1: 219 - 222. Cambridge University Press, Cambridge.

Bittrich, V. (1993). Caryophyllaceae. In: K. Kubitzki. \& J. W. Kadereit (eds), The families and genera of vascular plants, Magnoliid, Hamamelid and Caryophyllid families. Vol. 2: 206 - 236. Springer, Hamburg.

Bojňanský, V. \& Fargašová, A. (2007). Atlas of seeds and fruits of Central and East-European flora: the Carpathian mountains region, pp. 47 - 91. Springer, Dordrecht.

Budak, Ü. (2012). A new species of Gypsophila (Caryophyllaceae): Gypsophila yusufeliensis Budak, from Turkey. Ann. Bot. Fenn. 49: 425 - 427.

Cronquist, A. (1968). The evolution and classification of the flowering plants. Thomas Nelson Ltd., Edinburgh, London.

Cui, X., Wang, M., Lei, G. \& Jiaxi, L. (2019). Pollen morphology of Chinese Caryophylleae and its systematic significance. Palynology 43 (4): 574 - 584.

Davis, P. H. (1967). Flora of Turkey and the East Aegean Islands, Vol. 3: 645. Edinburgh University Press, Edinburgh.
Mill, R. R. \& Tan, K. (1988). Minuartia L. In: P. H. Davis, R. R. Mill \& K. Tan (eds), Flora of Turkey and the East Aegean Islands, Vol. 10: 67 - 69. Edinburgh University Press, Edinburgh.

Dillenberger, M. S. \& Kadereit, J. W. (2014). Maximum polyphyly: multiple origins and delimitation with plesiomorphic characters require a new circumscription of Minuartia (Caryophyllaceae). Taxon 63: $64-88$.

Erdtman, G. (1969). Handbook of palynology, morphology, taxonomy and ecology. Munksgaard, Copenhagen.

Fior, S. \& Karis, O. P. (2007). Phylogeny, evolution and systematics of Moehringia (Caryophyllaceae) as inferred from molecular and morphological data: a case of homology reassessment. Cladistics 23: 362 372.

Fu, X. P., Ning, G. G., Gao, L. P. \& Bao, M. Z. (2008). Genetic diversity of Dianthus accessions as assessed using 2 molecular marker systems (SRAPs and ISSRs) and morphological traits. Sci. Hort. (Amsterdam) 117: 263 - 270.

Frajman, B., Eggens, F. \& Oxelman, B. (2009). Hybrid origins and homoploid reticulate evolution within Heliosperma (Sileneae, Caryophyllaceae): a multigene phylogenetic approach with relative dating. Syst. Biol. 58: 328 - 345.

Hamzaoğlu, E. (2012). A new species of Gypsophila and a new name for Silene (Caryophyllaceae) from Turkey, Turk. J. Bot. 36: 35 - 139.

Harbaugh, D. T., Nepokroeff, M., Rabeler, R. K., McNeill, J., Zimmer, E. A. \& Wagner, W. L. (2010). A new lineage-based tribal classification of the family Caryophyllaceae. Int. J. Pl. Sci. 171 (2): 185 - 198.

Hernández-Ledesma, P., Berendsohn, W. G., Borsch, T., Mering, S. V., Akhani, H., Arias, S., CastañedaNoa, I., Eggli, U., Eriksson, R., Flores-Olvera, H., Fuentes-Bazán, S., Kadereit, G., Klak, C., Korotkova, N., Nyffeler, R., Ocampo, G., Ochoterena, H., Oxelman, B., Rabeler, R. K., Sanchez, A., Schlumpberger, B. O. \& Uotila, P. (2015). A taxonomic backbone for the global synthesis of species diversity in the angiosperm order Caryophyllales. Willdenowia 45: 281 - 383.

Hilooğlu, M., Poyraz, İ., Ataşlar, E. \& Sözen, E. (2016). Genetic relationships among some Turkish Petrorhagia (Ser.) Link (Caryophyllaceae) taxa using ISSR markers. Phytotaxa 272 (2): 165 - 172.

Huber-Morath, A. (1967). Gypsophila L. In: P. H. Davis (ed.), Flora of Turkey and the East Aegean Islands, Vol. 2: 149 - 171. Edinburgh University Press, Edinburgh.

IUCN (International Union for the Conservation of Nature) (2012). The IUCN Red List Categories and Criteria. Version 3.1. Second Edition. IUCN Species Survival Commission, Gland and Cambridge. 
Koç, M. (2013). Gypsophila torulensis (Caryophyllaceae) a new species from Turkey. Ann. Bot. Fenn. 50: 149 150.

, Hamzaoğlu, E. \& Aksoy, A. (2019). A new species and five new combinations of Sabulina (Caryophyllaceae) from Turkey. Folia Geobot. 54: $279-289$.

Korkmaz, M. \& Doğan, N. Y. (2015). Biogeographic pattern of genetic diversity detected by RAPD and ISSR analysis in Gypsophila (Caryophyllaceae) species from Turkey. Genet. Molec. Res. 14 (3): 8829 8838.

Mabberley, D. J. (2018). Mabberley's Plant-Book: A portable dictionary of plants, their classification and uses, fourth edition. Cambridge University Press, Yeni Delhi.

Madhani, H., Rabeler, R., Pirani, A., Oxelman, B., Heubl, G. \& Zarre, S. (2018). Untangling phylogenetic patterns and taxonomic confusion in tribe Caryophylleae (Caryophyllaceae) with special focus on generic boundaries. Taxon 67: 83 - 112 .

Özhatay, N. \& Kültür, Ş. (2006). Check-list of additional taxa to the supplement Flora of Turkey III. Turkish J. Bot. 30: $281-316$.

Özçelik, H. \& Özgökçe, F. (2021). Taxonomic contributions to genus Gypsophila in Turkey and a new taxon from Erzurum: G. venusta subsp. staminea. Anatolian J. Bot. 5 (1): 6 - 18.

Poyraz, İ. E., Sözen, E., Ataşlar, E. \& Poyraz, İ. (2012). Determination of genetic relationships among Velezia L. (Caryophyllaceae) species using RAPD markers. Turk. J. Biol. 36: 293 - 302.

Punt, W., Hoen, P. P., Blackmore, S., Nilsson, S. \& A. L. T. (2007). Glossary of pollen and spore terminology. Rev. Palaeobot. Palynol. 143 (1 - 2): 1 - 81.

Rautenberg, A., Hathaway, L., Oxelman, B. \& Prentice, H. C. (2010). Geographic and phylogenetic patterns in Silene section Melandrium (Caryophyllaceae) as inferred from chloroplast and nuclear DNA sequences. Molec. Phylogenet. Evol. 57: 978 - 991.

Rechinger, K. H. (1964). Gypsophila L. In: K. H. Rechinger (eds), Flora of Lowland Iraq, pp. 241 243. J. Cramer, Weinheim.

(1988). Gypsophila L. In: K. H. Rechinger (eds), Flora Iranica. Vol. 163: 206 - 246. Akademische Druck und Verlagsanstalt, Graz.

Sadeghian, S., Zarre, S., Rabeler, R. K. \& Heubl, G. (2015). Molecular phylogenetic analysis of Arenaria (Caryophyllaceae: Tribe Arenarieae) and its allies inferred from nuclear DNA internal transcribed spacer and plastid DNA Rps16 sequences. Bot. J. Linn. Soc. 178: 648 - 696.

Shishkin, B. K. (1970). Gypsophila L. In: B. K. Shishkin (ed.), Flora of the U.S.S.R. Vol. 6: 556 - 591. Israel Program for Scientific Translations, Jerusalem.

Thiers, B. M. (2021, continuously updated). Index Herbariorum: A Global Directory of Public Herbaria and Associated Staff. New York Botanical Garden's Virtual Herbarium. http://sweetgum.nybg.org/science/ ih/.

Walker, J. W. (1974a). Evolution of exine structure in the pollen of primitive Angiosperms. Amer. J. Bot. 61: $91-902$

(1974b). Aperture evolution in the pollen of primitive Angiosperms. Amer. J. Bot. 61: 1112 - 1137.

Yildiz, K. (2002). Seed morphology of Caryophylaceae species from Turkey (northern Anatolia). Pakistan J. Bot. 34: 161 - 171.

Zohary, M. (1966). Gypsophila L. In: M. Zohary (ed.), Flora Palaestina Vol. 1: 100 - 102. Israel Academy of Sciences and Humanities, Jerusalem.

\section{Publisher's Note}

Springer Nature remains neutral with regard to jurisdictional claims in published maps and institutional affiliations. 